\title{
Selection of Sustainable Performance Strategies in Cosmetics SMIs Using Lean and Green Balance Scorecards Methods
}

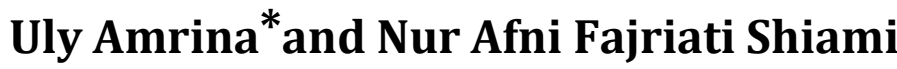

\author{
Industrial Engineering Department, Faculty of Engineering, Universitas Mercu Buana \\ Jl. Raya Meruya Selatan, Kembangan, Jakarta 11650 Indonesia \\ E-mail: uly.amrina@mercubuana.ac.id; afnishiami@gmail.com
}

*Corresponding author details: Uly Amrina; uly.amrina@mercubuana.ac.id

\begin{abstract}
Cosmetics SMI is experiencing problems assessing its business performance in the face of demands for sustainable industry transparency. They only assess their performance based on operation and financial aspects and pay less attention to environmental and social criteria. This research was conducted to assist the owner-manager of cosmetics SMI in designing criteria for measuring the performance of a sustainable SMI comprehensively and determining the right strategy to improve performance. The research team combined the Balanced Scorecards (BSC) method with four perspectives and performance indicators for lean and green manufacturing to support a sustainable SMI. That combination produces 18 lean and green criteria arranged from financial, customer, internal process, and growth and learning. Then, researchers prioritize these 18 criteria with the analytical hierarchy process (AHP) technique. The weighting results show that the financial criteria have the highest weight of $35.2 \%$ and the growth and learning criteria have the lowest weight of $13.7 \%$. The weighting calculation has a consistency value of 0.01 . Researchers recommend four strategies that can improve the criteria' performance based on weighting assessments at the sub-criteria level. The four strategies can accelerate the achievement of sustainable Cosmetics SMI.
\end{abstract}

Keyword: sustainability; lean and green; balanced scorecards (BSC); analytical hierarchy process (AHP); cosmetics SMI

\section{INTRODUCTION}

Cosmetics is a leading industry that started taking off in the millennial year. The spread of the coronavirus and its determination as a pandemic have also impacted the global cosmetics business. Euromonitor International predicts that this impact will last from 2020 to 2024. FIGURE 1 shows a $2 \%$ decrease in total sales of cosmetics (in units) in 2020 and is expected to increase again in 2021 due to increased demand for personal or personal care products [1]. Asia Pacific countries are declared as cosmetic, industrial areas with bright spots in 2021-2024 because they are systematically better at dealing with the coronavirus pandemic. The Asia Pacific dominates 55\% of world cosmetic sales, followed by Latin America with 12\%, Middle East and Africa 11\%. Although the Asia Pacific has predicted a positive sales trend, there is a change in society's cosmetic products' needs.

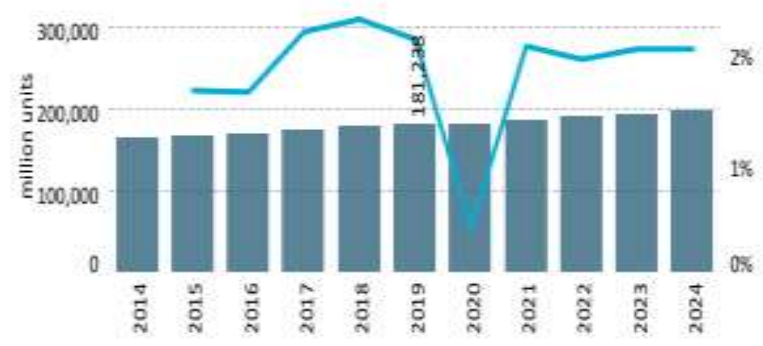

FIGURE 1: World Cosmetics Sales Trend 2021-2024 Source: [1]
Society redefines their need for health by shifting to the basic principles of self-health free from disease. People not only make sustainability a cosmetic trend, but they set sustainability as a life goal. They place everything not only from a profit perspective - but also on environmental and social responsibility. Sustainability in cosmetic customers' eyes is manifested in the transparency of business performance from the point of view of cosmetic products' safety, from the raw material content - the manufacturing process - to the delivery to the customer's door. Companies engaged in the cosmetics industry, including SMI, must answer the need for sustainability through transparency in measuring sustainability performance indicators. Unfortunately, Cosmetics SMI has limited resources and capabilities.

Owner managers, as decision-makers at Cosmetics SMI, find it challenging to carry out continuous performance appraisals. So far, they have only assessed financial performance, which is oriented towards achieving shortterm profits. To help achieve a sustainable assessment at SMI Cosmetics, the research team applied the Lean and Green Balance Scorecards method to assess companies holistically. Balanced Scorecards (BSC) are performance management tools that allow organizations to translate their corporate vision and strategy into implementation seen from four perspectives [2]. The four perspectives are financial, internal business, customer, and learning and growth perspectives. At the same time, Lean and Green is a concept that ensures the creation of a sustainable business 
by eliminating all types of waste that occur. Previous research has produced 17 sustainable factors for SMI Cosmetics related to the manufacturing, financial, environmental and social dimensions [3]. However, this research has not yet produced a measurable performance appraisal framework ready to be applied to SMI Cosmetics. This study will further explore the detailed scorecards used to measure sustainability performance as a reference for SMI Cosmetics. Researchers will also provide recommendations for strategies that can increase the performance value of SMI Cosmetics in the long term.

\section{LITERATURE REVIEW}

Sustainable industrial performance includes factors related to operational, economic, environmental and social dimensions. The operational and economic dimensions represent the outcome of the lean manufacturing concept. Meanwhile, the environmental and social dimensions are the focus of the green manufacturing concept. The operational dimension indicators are production resources, waste, productivity ratios, and quality ratios in the lean manufacturing concept. Simultaneously, the economic dimension includes metrics of production costs, company profits, and government revenue). In the green manufacturing concept, the environmental dimension can be measured from water, air and soil pollution, and the consumption of toxic chemicals). Meanwhile, the social dimension includes indicators of welfare, salary and benefits, and health of human resources). The four sustainability dimensions with lean and green indicators can be combined with measuring balanced scorecards' performance (BSC).

The critical role of the BSC is to align organizational strategy with performance, translating strategy into action [4]. A business needs to set clear strategic objectives in four perspectives: the desired financial performance, customer description, internal processes within the company, and employee competencies [5]. The customer perspective focuses on what the customer thinks about the company and how it wants its customers to see it [4]. Performance measures for this perspective include customer service, responding to customer requests quickly and confidently, and quality and performance. The internal business process perspective focuses on how well the business is running and the activities the organization carries out to satisfy customers, shareholders, surrounding communities, and the government. The financial performance perspective includes the profitability and cost-effectiveness of a strategy that will enable the organization to evaluate and measure its results [6].

Meanwhile, the learning and growth perspective includes employees' ability, skill level, employee satisfaction, and retention. The combination of mapping indicators for lean and green balanced scorecards is prepared in the framework of the sustainability performance of SMI Cosmetics.
Analytical Hierarchy Process (AHP) is a decision-making technique that can weigh lean and green BSC indicators.

AHP uses a questionnaire that is distributed to experts as a reference in making decisions. The measurement scale used in AHP uses the Saaty scale in the order of 1-9. A score of 1 indicates that the two elements are equally essential and increase in importance from the odd to absolute most important score at 9 . While the scores $2,4,6$, and 8 indicate the scores between two adjacent odd score considerations.

\section{METHODS}

The object of this research is SMI Cosmetics which is located in Indonesia, West Java. Researchers used the focus group discussion (FGD) method and literature studies to determine the sustainability performance scorecards. FGD is a qualitative research method appropriate to formulate a concept from several expert perspectives [7]. This research involved 5 SMI cosmetic experts who have more than 25 years of experience and are actively involved in the cosmetics entrepreneur association at the national level. Furthermore, the researchers weighted the performance scorecards through a questionnaire that was distributed to the five experts. The questionnaire's answers were processed with the Super Decision application's help based on the AHP method. The research steps are summarized in FIGURE 2.

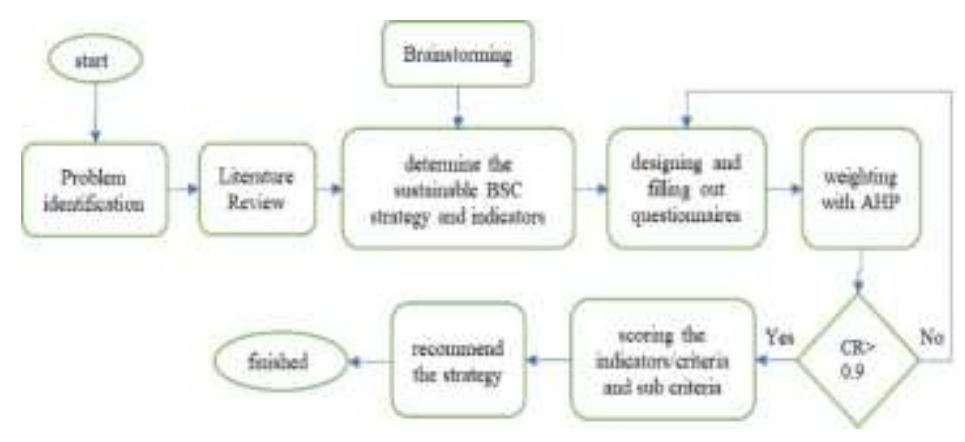

FIGURE 2: Research Steps

\section{RESULT AND DISCUSSION}

\section{Factor Identification}

Based on literature studies and expert interviews, the researchers formulated L\&G BSC to achieve a sustainable Cosmetic SMI, as shown in TABLE 1. This study considers four indicators: internal process, financial aspects, customer focus, and growth and learning, which break down into eighteen primary sub-indicators related to lean and green measurement. The internal process criteria are divided into six strategies related to lean and green indicators. The financial criteria consist of five strategies that can increase the stability of corporate profits and government revenues. Customer criteria include two strategies that represent customer needs. Furthermore, the growth and learning criteria include five strategies that show how SMI can develop sustainably in the future.

TABLE 1: Lean and Green Balance Scorecard (L\&G BSC) Model

\begin{tabular}{|c|c|c|c|c|}
\hline Perspectives & Strategic Objectives & Code & Indicators & References \\
\hline Internal Process & $\begin{array}{c}\frac{\text { Production Facility: Availability }}{\text { of production facilities and }} \\
\text { equipment following } \\
\text { regulations }\end{array}$ & $S 1-1$ & Facility Utilization & [8] \\
\hline Internal Process & $\begin{array}{c}\text { Quality Improvement: Quality } \\
\text { improvement activities } \\
\text { throughout the production } \\
\text { process }\end{array}$ & $S 1-2$ & Defect Ratio & [9], [10] \\
\hline
\end{tabular}




\begin{tabular}{|c|c|c|c|c|}
\hline Perspectives & Strategic Objectives & Code & Indicators & References \\
\hline Internal Process & $\begin{array}{l}\text { Productivity Control: } \\
\text { Production control that } \\
\text { ensures the value of output is } \\
\text { more significant than the input }\end{array}$ & $S 1-4$ & Productivity Ratio & [9], [10] \\
\hline Internal Process & $\begin{array}{c}\text { Environmental Impact: Reduce } \\
\text { the contamination from solid, } \\
\text { liquid, and low hazardous } \\
\text { waste. }\end{array}$ & $S 1-5$ & $\begin{array}{c}\text { Liquid Waste to } \\
\text { Target Achievement } \\
\text { Ratio }\end{array}$ & [12] \\
\hline Internal Process & $\begin{array}{l}\text { Green Brand Certification: } \\
\text { Green product certification } \\
\text { obtained by all cosmetic } \\
\text { variants produced }\end{array}$ & $S 1-6$ & $\begin{array}{l}\text { The existence of } \\
\text { Green Brand } \\
\text { Certification }\end{array}$ & {$[10]$} \\
\hline Financial & $\begin{array}{c}\text { Manufacturing Cost: Minimum } \\
\text { expenses through waste } \\
\text { elimination and productivity } \\
\text { improvement }\end{array}$ & $S 2-1$ & $\begin{array}{c}\text { Cost Reduction } \\
\text { Achievement Ratio }\end{array}$ & {$[13],[14]$} \\
\hline Financial & $\begin{array}{c}\text { Sales revenue: Increase in } \\
\text { income through creative } \\
\text { marketing programs }\end{array}$ & $S 2-2$ & Sales Increase Ratio & {$[13],[14]$} \\
\hline Financial & $\begin{array}{l}\text { Company profitability: } \\
\text { Achieving profit targets } \\
\text { through simultaneous activities } \\
\text { from various lines. }\end{array}$ & $S 2-3$ & Profitability Ratio & [13], [14] \\
\hline Financial & Tax Paid: Zero tax penalties. & $S 2-4$ & Tax issue & [15] \\
\hline Financial & $\begin{array}{l}\text { Government Subsidies: Get } \\
\text { capital assistance from the } \\
\text { government. }\end{array}$ & $S 2-5$ & $\begin{array}{l}\text { Government Funding } \\
\quad \text { for } R \& D\end{array}$ & [16] \\
\hline Customer & $\begin{array}{l}\text { Customer Satisfaction: } \\
\text { commerce programs that can } \\
\text { increase customer satisfaction }\end{array}$ & $S 3-1$ & Claim Rate & [9], [10] \\
\hline Customer & $\begin{array}{l}\text { Product Design/Formulation: } \\
\text { Safe and environmentally } \\
\text { friendly material formulation }\end{array}$ & S3-2 & $\begin{array}{l}\text { Number of product } \\
\text { approved and } \\
\text { registered by the } \\
\text { government }\end{array}$ & [17] \\
\hline $\begin{array}{l}\text { Growth and } \\
\text { Learning }\end{array}$ & $\begin{array}{l}\frac{\text { Emission/Residual Reduction }}{\text { Program: Company activities to }} \\
\text { reduce emissions }\end{array}$ & $S 4-1$ & $\begin{array}{l}\text { Number of Emission } \\
\text { Reduction Program }\end{array}$ & [18] \\
\hline $\begin{array}{l}\text { Growth and } \\
\text { Learning }\end{array}$ & $\begin{array}{l}\text { HR Health and Safety: Health } \\
\text { and safety improvement } \\
\text { programs in collaboration with } \\
\text { government agencies and local } \\
\text { health centres }\end{array}$ & $S 4-2$ & $\begin{array}{c}\text { Number of Working } \\
\text { Accident }\end{array}$ & [10] \\
\hline $\begin{array}{l}\text { Growth and } \\
\text { Learning }\end{array}$ & $\begin{array}{c}\text { HR Wealth: Providing } \\
\text { incentives and fulfilling the } \\
\text { average income of cosmetic } \\
\text { workers according to regional } \\
\text { minimum wages }\end{array}$ & $S 4-3$ & $\begin{array}{l}\text { The ratio of Average } \\
\text { HR Salary to Regional } \\
\text { Minimum Wages }\end{array}$ & [10] \\
\hline $\begin{array}{l}\text { Growth and } \\
\text { Learning }\end{array}$ & $\begin{array}{l}\text { HR Capability: Training } \\
\text { programs and On Job } \\
\text { Development to improve HR } \\
\text { capabilities or skills }\end{array}$ & $S 4-4$ & $\begin{array}{c}\text { Number of Trained } \\
\text { Employee/Year }\end{array}$ & [17] \\
\hline $\begin{array}{l}\text { Growth and } \\
\text { Learning }\end{array}$ & $\begin{array}{l}\text { Use of Resources: Effectiveness } \\
\text { of the use of human resources }\end{array}$ & $S 4-5$ & Attendance Ratio & [8] \\
\hline
\end{tabular}




\section{Model Hierarchy Development}

In this section, the researcher compiles a hierarchy of sustainability performance models based on Lean and Green BSC in the cosmetics industry, as shown in FIGURE 3.

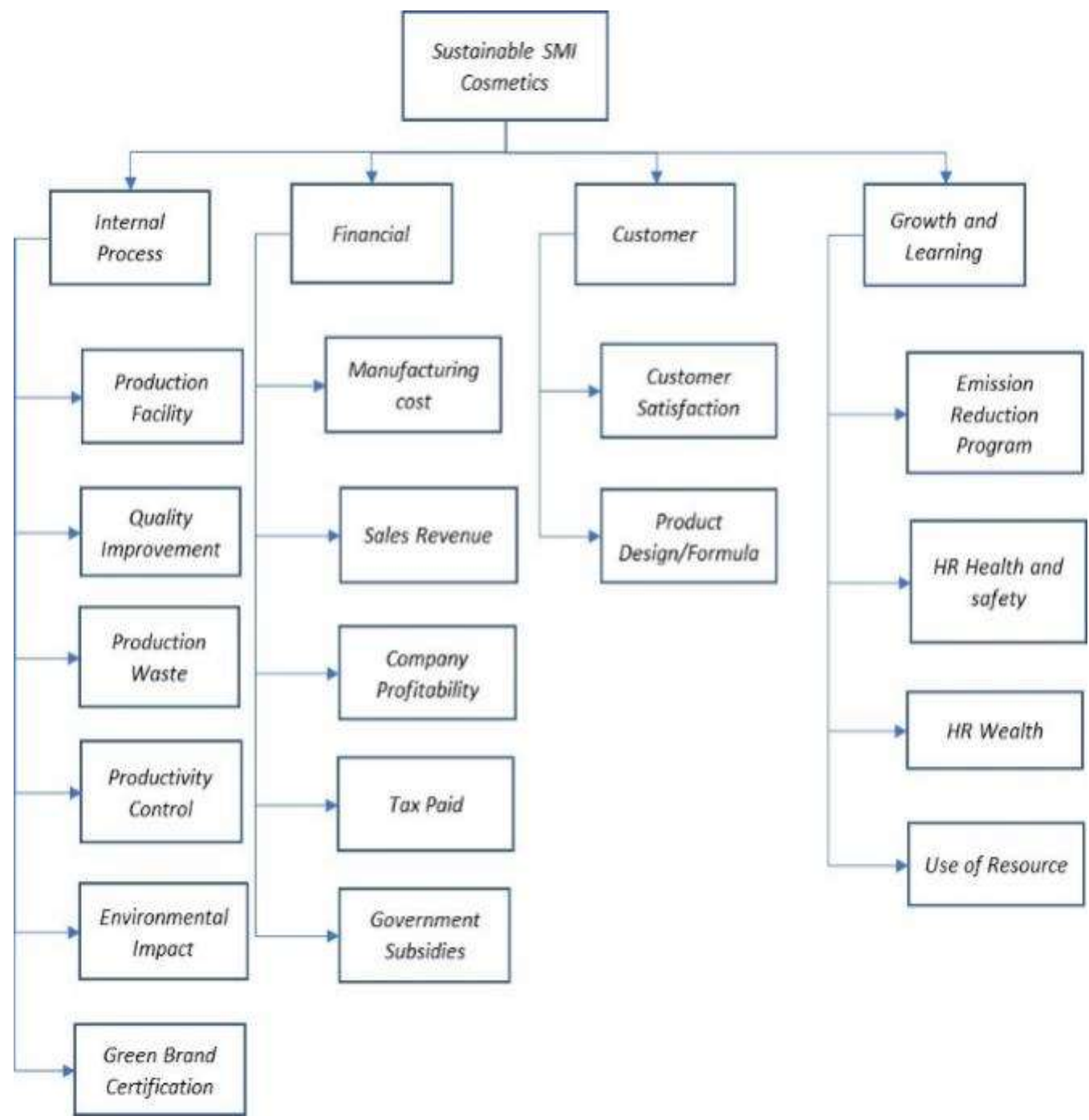

FIGURE 3: Hierarchical Structure of the BSC Lean and Green Performance Model

\section{Weighting Criteria and Sub Criteria}

After forming the BSC lean and green strategy model hierarchy, the next step is to decide which criteria will be prioritized to be monitored intensively every month. The method used is the AHP approach, and the tool used to calculate the weight is a questionnaire given to 5 people who are considered experts because they have become representatives of stakeholders. TABLE 2 shows the results of the pairwise comparison calculation of the four BSC lean and green criteria.
The inconsistency ratio of the pairwise comparison in the criteria level was 0.01 . It was stated that the weighting was consistent because the number was below 0.10. Based on TABLE 2, financial scorecards are prioritized by companies with a weight of 0.352 . The company also has to boost customer aspects, internal processes, and growth and learning in consecutive priority positions to support financial performance criteria. If SMIs can maximize those criteria performance, they will possibly generate optimum results of financial aspects.

At the sub-criteria level, the research team also weighted using the same method as for TABLE 3 .

TABLE 2: Pairwise Comparison Calculation Results at Criteria Level

\begin{tabular}{|c|c|c|c|c|c|c|}
\cline { 2 - 7 } \multicolumn{1}{c|}{} & Financial & Customer & $\begin{array}{c}\text { Internal } \\
\text { Process }\end{array}$ & $\begin{array}{c}\text { Growth and } \\
\text { Learning }\end{array}$ & $\begin{array}{c}\text { Geometric } \\
\text { Mean }\end{array}$ & $\begin{array}{c}\text { Relative } \\
\text { Weight }\end{array}$ \\
\hline Financial & 1.00 & 1.19 & 2.05 & 2.35 & 1.55 & 0.352 \\
\hline Customer & 0.84 & 1.00 & 2,77 & 2,35 & 1.53 & 0.350 \\
\hline Internal Process & 0.49 & 0.36 & 1.00 & 1,40 & 0.70 & 0.161 \\
\hline $\begin{array}{c}\text { Growth and } \\
\text { Learning }\end{array}$ & 0.43 & 0.43 & 0.72 & 1.00 & 0.60 & 0.137 \\
\hline Total & 2.75 & 2.98 & 6.53 & 7.10 & 4.38 & 1 \\
\hline
\end{tabular}


TABLE 3: Weighted Calculation Results at Sub Criteria Level

\begin{tabular}{|c|c|c|c|}
\hline Code & Sub Criteria & $\begin{array}{c}\text { Relative Weight to } \\
\text { Each Criterion }\end{array}$ & $\begin{array}{c}\text { Absolute Weight to } \\
\text { Each Criterion }\end{array}$ \\
\hline S3-1 & Customer Satisfaction & 0,645 & 0,225 \\
\hline S3-2 & Product Design/Formula & 0,355 & 0,124 \\
\hline S2-2 & Company Profitability & 0,284 & 0,100 \\
\hline S2-3 & Sales Revenue & 0,272 & 0,096 \\
\hline S2-1 & Manufacturing Cost & 0,194 & 0,069 \\
\hline S2-5 & Tax Paid & 0,130 & 0,046 \\
\hline S2-4 & Government Subsidies & 0,120 & 0,043 \\
\hline S4-4 & HR Capability & 0,280 & 0,038 \\
\hline S1-4 & Environmental Impact & 0,230 & 0,037 \\
\hline S4-2 & HR Wealth & 0,252 & 0,035 \\
\hline S4-1 & HR Health and Safety & 0,237 & 0,032 \\
\hline S1-5 & Production Waste & 0,193 & 0,031 \\
\hline S1-2 & Productivity Control & 0,179 & 0,029 \\
\hline S1-1 & Quality Improvement & 0,154 & 0,025 \\
\hline S1-3 & Green Brand Certification & 0,130 & 0,021 \\
\hline S1-6 & Production Facility & 0,114 & 0,018 \\
\hline S4-5 & HR Satisfaction & 0,130 & 0,018 \\
\hline S4-3 & Emission Reduction Program & 0,100 & 0,014 \\
\hline
\end{tabular}

Customer satisfaction is the ultimate goal from a financial perspective, measured by the low level of customer complaints. The company maintains the presence of its customers by maintaining product quality. The quality of cosmetic products is determined by product formulations guaranteed to be safe and environmentally friendly.
The researchers compiled a strategy map based on brainstorming with experts by referring to the weighting criterion and sub-criteria level. FIGURE 4 depicts a strategy map that can be applied to SMI's cosmetics in the future.
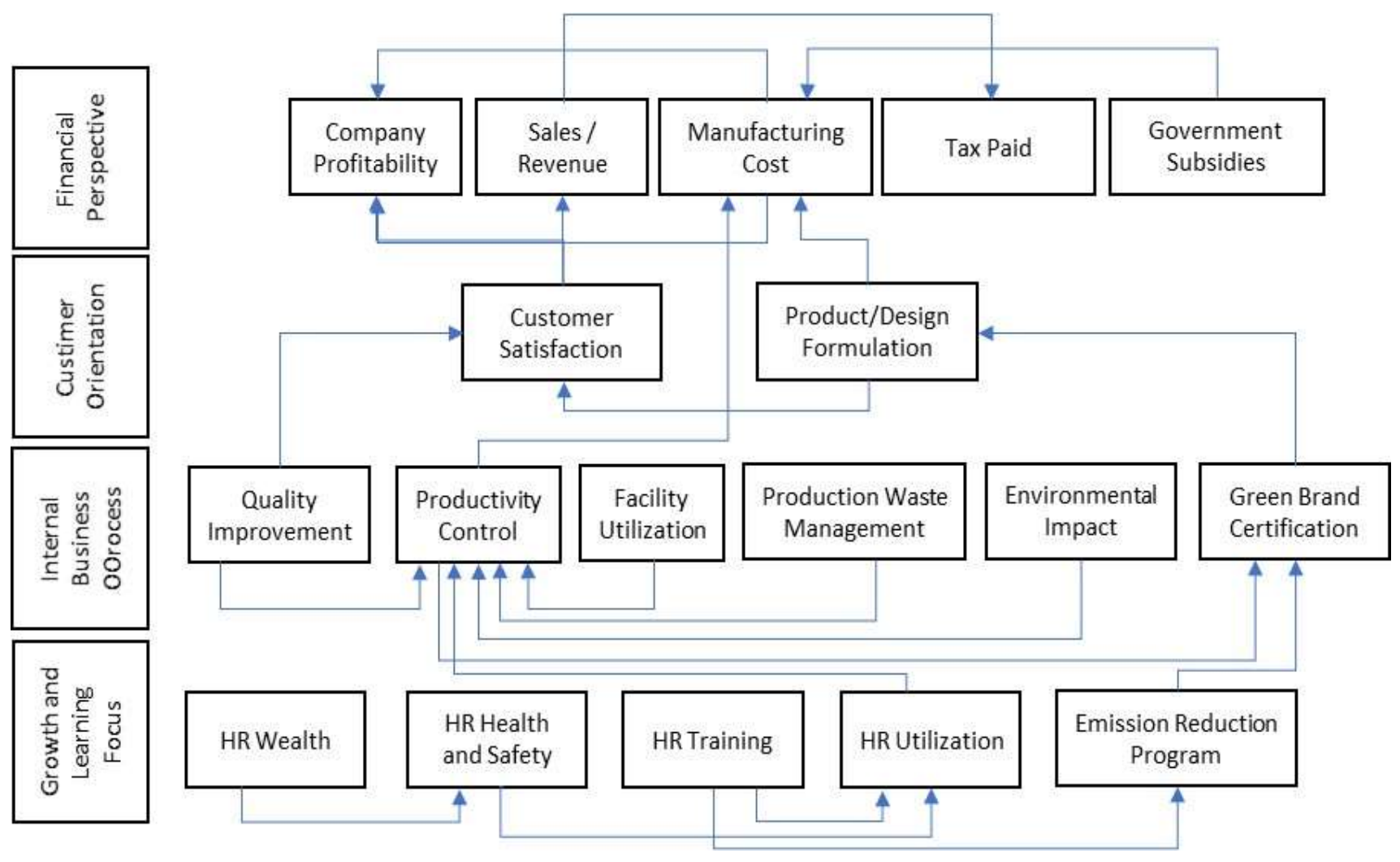

FIGURE 4: The Strategic Mapping of Cosmetics SMI 
The researcher proposes four priority strategies to maintain and improve the performance of several indicators with the foremost priority in the short term, namely:

a. Conduct research of new product utilizing natural, halal, and environmentally friendly material formulations to increase sales and environmental performance. Innovations in product formulations can increase customer satisfaction and generate optimum profits.

b. Increase profit stability without increasing product prices by applying kaizen techniques to improve productivity and minimize manufacturing costs. The kaizen techniques scopes are including eight waste minimization both in the production process or environmental impact.

c. Develop e-commerce strategies and customer relationship programs promoting green brand certification. The activities will bring products closer to society and meet customer needs.

d. Health care for workers through environmentally friendly programs, CSR, and collaboration with local health centres for routine health checks.

\section{CONCLUSIONS}

The researchers obtained four criteria for a sustainable SMI Cosmetic assessment based on the lean and green BSC based on the literature. From the four assessment criteria the research team divided them into 18 sustainability strategies with different weights. The internal process criteria have six strategies, the financial criteria consist of five strategies, the customer criteria are divided into two strategies, and the growth and learning criteria develop five strategies. The design and distribution of questionnaires to 5 experts have been carried out to model each criterion and strategy's priority. Financial criteria have the highest priority of 0.352 , and a customer satisfaction strategy is the highest priority to implement. The researcher proposes four main strategies to improve the performance of priority indicators. The first is to develop e-commerce strategies and customer relationship programs that bring products closer to society and meet customer needs. The second is to increase profit stability without increasing product prices, namely by applying kaizen techniques to improve quality and minimize manufacturing costs. The third is to formulate new, environmentally friendly materials to increase sales and environmental performance. The fourth is maintaining worker health through environmentally friendly programs, CSR, and cooperation with local health centres for routine health checks. The implementation of an effective strategy will support the achievement of sustainable SMI Cosmetics.

\section{ACKNOWLEDGMENT}

The authors wish to acknowledge Universitas Mercu Buana Research Center for funding this research. We are also grateful for all experts willing to be research partners, with no mention of the company name.

\section{REFERENCES}

[1] Euromonitor International. (2020). Word Market for Beauty and Personal Care.

[2] Meena, K. \& J. Thakkar. (2014). Development of Balanced Scorecard for Healthcare Using Interpretive Structural Modeling and Analytic Network Process. Journal of Advances in Management Research.

[3] Amrina, U. \& A. Oktora. (2020). Analysis of Lean and Green Drivers for Sustainable Cosmetics Smis Using Interpretive Structural Modelling (Ism). International Journal of Engineering Research and Advanced Technology-IJERAT (ISSN: 2454-6135), 6(5), 8-16. f
[4] Kaplan, R.S. \& D.P. Norton. (1996). Using the Balanced Scorecard as a Strategic Management System.

[5] Constandache, N. \& G. Chiru. (2016). Balanced Scorecard: Organizational Performance Management Instrument. EuroEconomica, 34(2).

[6] Santos, B.D.S. (2006). The Rise of the Global Left: The World Social Forum and Beyond. Vol. 1. Zed Books.

[7] Morgan, D.L. (2012). Focus Groups and Social Interaction, in The Sage Handbook of Interview Research: The Complexity of the Craft. SAGE Publications, Inc. p. 161-176.

[8] Garbie, I.H. (2015). Integrating Sustainability Assessments in Manufacturing Enterprises: A Framework Approach. International Journal of Industrial and Systems Engineering, 20(3), 343-368.

[9] Fercoq, A., S. Lamouri, V. Carbone, A. Lelièvre, \& A.-A. Lemieux. (2013). Combining Lean and Green in Manufacturing: A Model of Waste Management. IFAC Proceedings Volumes, 46(9), 117-122.

[10] Wang, Z., N. Subramanian, A. Gunasekaran, M.D. Abdulrahman, \& C. Liu. (2015). Composite Sustainable Manufacturing Practice and Performance Framework: Chinese Auto-Parts Suppliers' Perspective. International Journal of Production Economics, 170, 219-233.

[11] Wang, X. (2015). A Comprehensive Decision-Making Model for the Evaluation of Green Operations Initiatives. Technological Forecasting and Social Change, 95, 191-207.

[12] Pinto-Ferreira, L., S. Ortigueira, E. Gómez, G. Lourido, \& J. Areal. (2015). Index of Economic and Functional Efficiency of a Sustainable Production Line. Procedia engineering, 132, 39-45.

[13] Aguado, S., R. Alvarez, \& R. Domingo. (2013). Model of Efficient and Sustainable Improvements in a Lean Production System through Processes of Environmental Innovation. Journal of Cleaner Production, 47, 141-148.

[14] Hallam, C. \& C. Contreras. (2016). Integrating Lean and Green Management. Management Decision, 54(9), 2157-2187.

[15] Arif, H., N.J. Faraz, \& D. Atika. (2019). Marketing as a Government Program Priority in Optimizing the Regional Superior Product. Paper presented at the International Conference of Ethics on Business, Economics, and Social Science (ICEBESS 2018).

[16] Nallusamy, S., G. Dinagaraj, K. Balakannan, \& S. Satheesh. (2015). Sustainable Green Lean Manufacturing Practices in Small Scale Industries-a Case Study. International Journal of Applied Engineering Research, 10(62), 143-146.

[17] Bandehnezhad, M., S. Zailani, \& Y. Fernando. (2012). An Empirical Study on the Contribution of Lean Practices to Environmental Performance of the Manufacturing Firms in Northern Region of Malaysia. International Journal of Value Chain Management, 6(2), 144-168

[18] Baines, T.S., S. Brown, O. Benedettini, \& P.D. Ball. (2012). Examining Green Production and Its Role within the Competitive Strategy of Manufacturers. 